\title{
MONDO az iskolában
}

\section{A jogok élvezetét ritkán kínálja aranytálcán az élet. Készüljünk fel, mert a jogokért való küzdelem kul- csa a jogtudatosság.}

A Társaság a Szabadságjogokért a MONDO nevű kártyajátékot azért fejlesztette ki, hogy a fogyatékossággal élő gyermekek minél korábban, már iskoláskorban tanuljanak a jogaikról játékos formában. A sokszor tabu témákat feldolgozó kártyák konkrét helyzeteket mutatnak be, illetve konkrét segítséget adnak abban, hogy ezekben a helyzetekben hogyan viselkedjünk, hogyan védjük meg magunkat. A MONDO tíz témaköre szervesen kapcsolódik az iskolai tantárgyak tematikáihoz, a pedagógusok visszajelzései alapján a kártyák hasznos eszközként szolgálnak az órákra való felkészülés során. A MONDO komplex keretrendszert biztosít, amely támogatja a pedagógusok jogtudatosságát, amely a gyermekek jogtudatos viselkedéséhez szükséges ismeretek, készségek és attitűdök átadásának alapja.

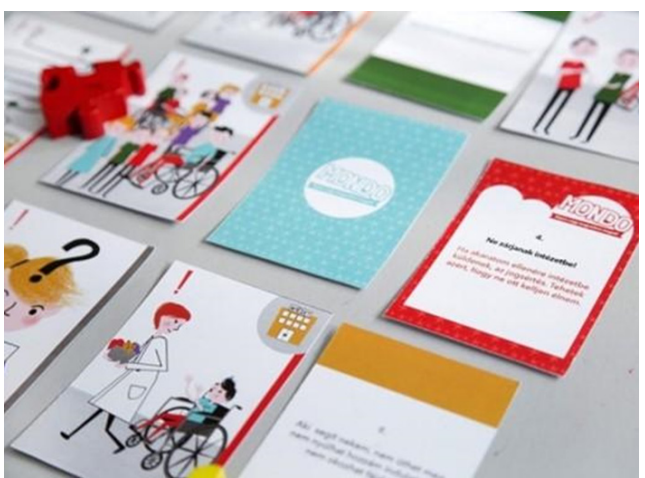

1. KÉP: A MONDO kártyák

A MONDO a Társaság a Szabadságjogokért (TASZ) jogvédő szervezet és a Csillagház Általános Iskola által kifejlesztett jogtudatosító kártyajáték. Egy sikeres közösségi adománygyűjtésnek köszönhetően 2019-ben 40 iskolába juthat el ingyenesen a pedagógusoknak szóló MONDO-workshop. A kétórás foglalkozáson a MONDO témáiról és a kártyák iskolai keretek között való használhatóságáról beszélgetünk.

Az írás elején a MONDO-t egy tágabb, az emberi jogi nevelés kontextusába helyezem, röviden bemutatom az emberi jogi oktatással kapcsolatos hazai fejleményeket. Ezt követően röviden kitérek a MONDO szemléletére, bemutatom a hátterét és a témáit, a workshop felépítését, majd megosztom a képzések során szerzett tapasztalataimat, rálátást adva arra, hogy a terepen dolgozó szakemberek - elsősorban gyógypedagógusok - mit gondolnak a kártyákról, illetve, hogy a visz- 
szajelzéseik alapján mennyire tartják a MONDO-t jól alkalmazható eszköznek a munkájuk során.

\section{Emberi jogi oktatás Magyarországon}

A Hintalovon Alapítvány 2019-es, az ENSZ Gyermekjogi Bizottsága számára készített jelentése 5300 gyerek véleményét mutatja be arról, hogy milyen ma Magyarországon felnőni (https://hintalovon.hu/sites/default/files/tehogylatod_jelentes_magyar.pdf). A gyerekjelentés egyediségét az adja, hogy az érintettek maguk értékelik a gyermekjogok helyzetét. A fiatalok több mint $80 \%$-a fontosnak tartja, hogy tisztában legyen a legfrissebb információkkal, hírekkel, viszont ugyanezen csoport majdnem fele sok mindent nem ért, ami körülötte történik a nagyvilágban, vagy nem tudja, hogy hol tájékozódjon. Az információhiány a jogtudatosság terén is megjelenik.

Sokatmondó eredmény, hogy feleannyi gyerekkel beszélgetnek a jogairól, mint a kötelességeiről. Öt gyerekből négy hallott a kötelességeiről, de csak kettővel beszélgettek a jogaikról. A fővárosban némileg jobb ez az arány, itt a gyerekek körülbelül fele hallott a jogaikról, köztük több a fiú, mint a lány. Az iskolai jogtudatosítás hiányosságaira továbbá az mutat rá, hogy a jogokról és kötelezettségekről (elsősorban utóbbiakról) inkább a családokban esik szó.

Pedig a tanároknak rendelkezésre állnak eszközök, útmutatók az emberi jogok oktatásához. Már a kilencvenes évek közepe óta elérhetőek magyar nyelvü kiadványok, képzési segédanyagok, amelyeket segítségül hívhatnak, hogy az emberi jogokat átültessék a pedagógiai gyakorlatukba. Említésre méltó, hogy 1999-ben jelent meg a Kezdő lépések és a Képzők könyve először magyarul, melyek módszertani útmutatóul és konkrét ötletgyűjteményként szolgálnak az emberi jogok iránt érdeklődő tanárok számára (Kezdő lépések: http://www.kozeletre.mediacenter6. hu/wp-content/uploads/2011/09/kezdolepesek.pdf és Képzők könyve (eredetije 1995-ben készült a Te is más vagy - te sem vagy más! elnevezésű, a fajgyűlölet és az intolerancia elleni európai ifjúsági kampány segédanyagaként): http://www. unp.hu/sites/default/files/imuk/pdf/kepzok_konyve_2006.pdf). Azóta több magyar nyelvü kiadvány is napvilágot látott: a korábbiaknál jóval részletesebb Kompasz kézikönyv a fiatalok emberi jogi képzéséhez 2004-ben, a fiatalabb korosztály, 7-13 éves gyermekek számára készült Kiskompasz 2009-ben jelent meg (Kompasz: https://rm.coe.int/kompasz-hun-2004/16808cf89b és Kiskompasz: https://rm.coe. int/2009-compasito-hu-with-cover/168075abf6). A Kiskompasz a módszertani útmutatás mellett 40 darab, 3 nehézségi szintű gyakorlatot tartalmaz különböző témakörökben (például: általános emberi jogok, állampolgárság, demokrácia, diszkrimináció). Szintén 2009-ben jelent meg a SINOSZ kiadásában Emberi Jogok. IGEN! című kiadvány, amely a fogyatékossággal élő személyek jogainak képzési kézikönyve. Megemlítendő még két újabb kézikönyv: a 2015-ben megjelent Tükrök, amely a rasszizmus, cigányellenesség témáját feldolgozó 18 gyakorlatot tartalmaz, illetve a 24 gyakorlatot magában foglaló Böngésző, amely az online gyűlöletbeszéd elleni ifjúsági kampányhoz, a No Hate Speech Mozgalomhoz kapcsolódóan 2016ban jelent meg (Tükrök: https://rm.coe.int/mirrors-hun-web/16808cf807 és Böngésző: https://rm.coe.int/16806f9ac6).

Az Emberi Jogi Nevelők Hálózata (EJHA) 2017-ben alakult, célja, hogy segítse az együttműködést és az információáramlást az emberi jogi nevelés területén aktív 
szakemberek és civil szervezetek között. A hálózat létrejötte azért is kiemelten fontos, mert 2018-as gyorsjelentésükböl az derült ki, hogy a válaszadó pedagógusok iskoláinak több mint $60 \%$-a nem állt kapcsolatban emberi jogi civil szervezetekkel. (EJHA 2018-as gyorsjelentése: http://ejha-halozat.hu/wp-content/uploads/2018/09/ EJHA-gyorsjelent\%C3\%A9s-1.pdf).

Az iskolák és a civilek közötti kapcsolat megerősödését az elmúlt évek civilellenes kormányzati narratívája nem segítette elö. A köznevelési törvény 2019. július 26-tól hatályos módosítása során bekerült gumiszabály kilátásba helyezi az igazgatókkal szembeni szankció alkalmazásának lehetőségét, az oktatásért felelős miniszter, az intézményvezető megbízását egy éven belül visszavonhatja, ha az iskolában olyan nevelési-oktatási vagy tájékoztató tevékenység folytatására került sor, amely „a köznevelési jogszabályok súlyos megsértése révén a gyermek, tanuló Alaptörvényben foglalt jogainak megsértését eredményezheti." A jogok ismerete kölcsönösségre, egymást tiszteletére tanít, az emberi jogokkal kapcsolatos jogtudatosítás aligha vezethet a tanulók alapjogainak sérelméhez. Mégis tudunk olyan igazgatóról, aki emiatt a passzus miatt nem meri a korábban az iskolájába bejáratos jogtudatosítást végző civileket beengedni. (Erről itt olvashat még: https://abcug.hu/ ferde-szemmel-neznek-rajuk-ha-az-emberi-jogokrol-tanitanak/)

2019 januárjában alakult az EJHA legújabb projektje, az EjhaCKni munkacsoport, amely az emberi jogi oktatásért tenni akaró tanárokat és civileket fogja öszsze. 2019 december 3-ra, a fogyatékossággal élő emberek világnapjára tervezik egy kiadvány megjelenítését, amelyben aktuális emberi jogi témájú (pl. szexizmus, hajléktalanság, fenntarthatóság) óraterveket talál majd az érdeklődő pedagógus, illetve a Civil Kurázsi program keretén belül civil szervezetek által meghirdetett iskolai programok katalógusát.

A 2018 februárjában alakult Sokszínűség Oktatási Munkacsoport (SOM) az iskolai zaklatás, sérülékeny társadalmi csoportokkal szembeni elöítéletek kezelésében nyújt módszertani segítséget tanároknak. Honlapjukon elérhető a „Te mit csinálnál Dia helyében?" címủ iskolai zaklatásról szóló kisfilm, amely jó alapot ad ahhoz, hogy a diákok az egymásért való kiállás jelentőségéről, a zaklatás elleni fellépés nehézségeiről, illetve a segítségnyújtás lehetséges módjairól beszélgessenek (http:// www.sokszinusegoktatas.hu/hirek/te-mit-csinalnal-kisfilmunk-az-iskolai-zaklatasrol). A SOM továbbá a tavaly először megrendezésre került Iskolai Sokszínűség Hetéhez készített egy javaslatcsomagot, amelyből az iskolák, egyes pedagógusok szabadon azt valósíthattak meg, amire igényt tartottak. Az Iskolai Sokszínüség Hete megrendezéséhez készült tanári kézikönyvben például szerepelnek ötletek a kisfilm feldolgozásához, további óratervek, gyakorlatok, illetve egy bullying kisokos (http:// sokszinusegoktatas.hu/sites/default/files/uploads/sh-tanari-kezikonyv-online.pdf).

\section{A MONDO SZEMLÉLETE}

A MONDO azon alapvetésből indul ki, hogy mindenkit egyenlően megillet a szabadság és az emberi méltóság. Messzemenő társadalompolitikai következményei vannak annak az egyszerü, de eszmetörténetileg radikális gondolatnak, hogy a fogyatékossággal élő embereknek ugyanolyan emberi jogai vannak, mint bárki másnak. Az egyenlőség elvéből fakadó követelmények feladatot rónak az államra, mégpedig 
azt, hogy biztosítsa minden állampolgára számára a hátrányos megkülönböztetés tilalmának megvalósulásához szükséges jogi, szociális, kulturális stb. feltételeket. Vagyis az államnak nem az a feladata, hogy különleges bánásmódban részesítse a rászoruló polgárokat, hanem hogy biztosítsa azokat a támogató rendszereket, amelyek segítségével a fogyatékossággal élő emberek is élni tudnak ugyanazokkal a jogokkal, mint a többségi társadalom.

Az egyenlőséget sokféleképpen lehet értelmezni. Ennek illusztrálására jó példa az a téves elképzelés, hogy jó az, ha sok fogyatékossággal élő ember él együtt nagy tömegintézményekben, hiszen sok hasonló szükségletű ember egy helyen megkaphatja az életvezetéséhez szükséges támogatást. Ezzel szemben a nemzetközi jog szellemében a MONDO azt képviseli, hogy önmagában a nagyintézmény jogsértő. Azért nincs olyan, hogy jó a nagyintézmény, mert az intézmény természetéből fakadóan - szigorú napirend, üzemszerűség, rugalmatlan, egyéni igényekre, preferenciákra reagálni képtelen struktúra - korlátozódik a lakók döntési autonómiája, választási szabadsága, amely rendeltetésszerűen vezethet nap mint nap a lakók emberi jogainak sérelmeihez.

Történelmi és jelenkori tapasztalat, hogy a mindenkit megillető egyenlőség, méltóság és szabadság a fogyatékossággal élő emberek hétköznapi életében kevéssé érvényesülnek. Az egyenlő jogok sokszor csak hangzatos szólamokként csengenek. Nem arról van szó, hogy a fogyatékosággal élő emberek másokhoz képest csak kevésbé tudnak élni a jogaikkal. Esetükben nem véletlenszerüek, nem pedig egyediek a jogsértések; könnyen válnak rendszerszintü jogfosztás és társadalmi kirekesztés áldozatává. Nem túlzás azt állítani, hogy ma Magyarországon fogyatékossággal élni gyakran még mindig egyet jelent a persona non grata státusszal: nem kívánatosnak lenni. A MONDO ezeket a leggyakoribb, tömegesen előforduló jogsértéseket mutatja be: bántalmazás, önrendelkezés hiánya, egészségügy, családjog, pénzügyek, lakóhely megválasztása kapcsán, (köz)szolgáltatásokhoz való egyenlő esélyű hozzáférés hiánya, politikai jogok: választás és választhatóság korlátozása.

A MONDO-szemlélet alapjául szolgáló Fogyatékossággal élő személyek jogairól szóló ENSZ egyezmény a fogyatékosságügy szemüvegén keresztül deklarálja az emberi jogokat. Az ENSZ egyezmény mindenki számára kedvező társadalmi következményekkel kecsegtet, pozitív irányú, inkluzív társadalmi változások nemzetközi jogi alapjait fekteti le. Magyarország 2007-ben ratifikálta az ENSZ egyezményt, ennek köszönhetően a hazai jogrendszerben elöremutató változások történtek. Ahhoz, hogy a progresszív jogszabálymódosításoknak pozitív hatása legyen az érintett emberek életére, elengedhetetlen a fogyatékossággal élő személyekkel és jogaikkal kapcsolatos társadalmi tudatosság növelése.

A jogtudatosság révén válik a jogvédők által hangoztatott emberi jogi szólamokból valódi eszköz a fogyatékossággal élő emberek, családjaik és szövetségeseik (pl. pedagógusok) kezében. Az emberi jogok mellett való kiállás szükséges a társadalmi hátrányok leküzdéséhez; megfelelő tudás birtokában képessé válhatunk a jogállamiság intézménye által garantált alapjogainkat érvényesíteni. Ha nem ismerjük a jogainkat, az élet nem kínálja azokat aranytálcán. A jogsérelmeket tudatosan meg lehet előzni, sérelem esetén tudatos állampolgárként fel tudunk lépni a jogaink védelmében. Ehhez kínál támpontot a MONDO. 


\section{A MONDO HÁTTERE}

A MONDO ötlete 2014-ben pattant ki Verdes Tamás gyógypedagógus, a TASZ fogyatékosságügyi programvezetőjének a fejéből. A témakörök hátterét a TASZ jogsegélyszolgálatához telefonon és e-mailen beérkező megkeresések adták. A kártyák mögött személyes történetek bújnak meg, azon, jogaikat érvényesíteni kívánó polgárok történetei, akik jogi tanácsért fordultak a TASZ-hoz. Ilyen például egy gondnoksági per kapcsán beérkező jogsegélykérelem annak érdekében, hogy a bíróság minél kevésbé korlátozza a fogyatékossággal élő személy döntési jogát. Az a tapasztalat, hogy az érintettek kevéssé tudják képviselni érdekeiket a gondnoksági perek során. Amikor az eljárás elindul - akár egy megalapozatlan kórházi jelzés, egy elmérgesült családi konfliktus, esetleg az ellátások elvesztésért való aggodalom miatt -, az érintettek tanácstalanul forgatják az érthetetlen nyelvezetű bírósági papírokat.

Milyen jó lenne, ha a jogsérelmeket meg lehetne előzni! Ehhez maguknak az érintetteknek kell felvértezve állniuk az őket érintő lehetséges veszélyhelyzetek előtt, hogy a megfelelö tudás birtokában azokat ki tudják kerülni, vagy gyorsan és hatékonyan meg tudják védeni magukat, ha jogsérelem éri őket. A MONDO gondolata ebből a felismerésböl született meg. A játék célja, hogy a fogyatékossággal élő személyek minél hamarabb, már gyermekkorban elkezdjenek a jogaikról játékos formában tanulni. Az iskolában eltöltött évek alatt így egyre jogtudatosabbá válnak, ön- és társismeretet szereznek, tanulnak az őket körülvevő világról, ennek köszönhetően felnőttként kompetensek lesznek jogaikat érvényesíteni, megvédeni.

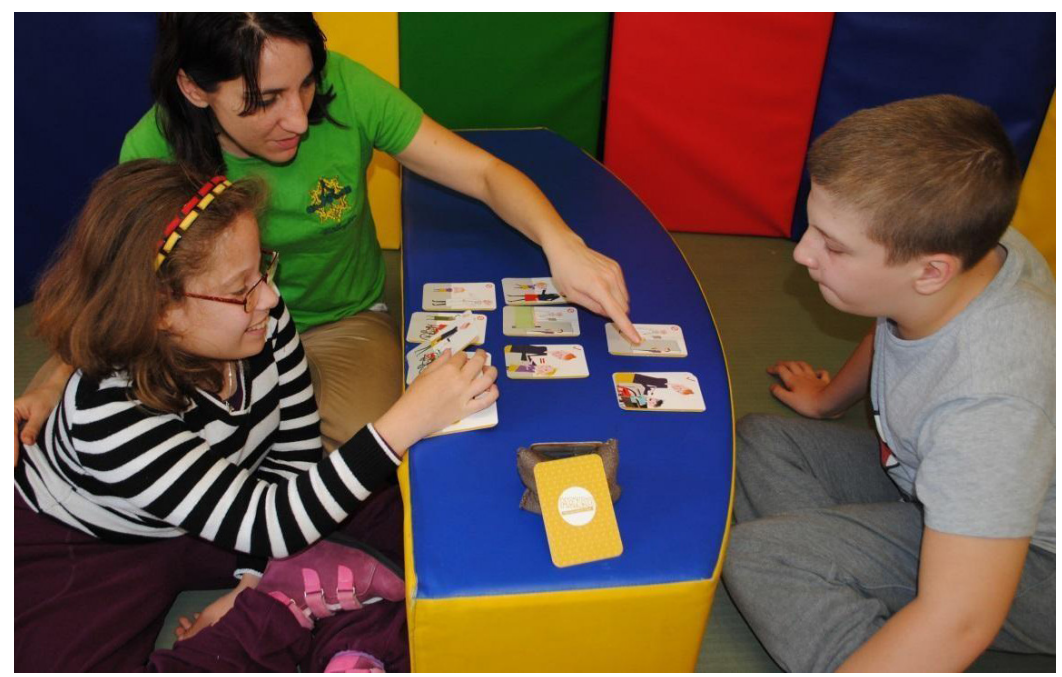

2. KÉP: MUNKA A MONDO-VAL

A 2015/16-os tanévben a kártyák első verziójával a Csillagház Általános Iskola pedagógusai dolgoztak a felsős 5-8. évfolyamos osztályokban. A Csillagházba mozgáskorlátozott, halmozott fogyatékossággal élő tanulók járnak, akik az átlagosnál több tapasztalattal rendelkeznek egészségügyi kezelésekről. Ezekröl az élményekröl szívesen beszéltek, igényük volt megosztani a kórházban átélteket. A gyerekek 
visszajelzései alapján a tesztelést követően több módosításra is sor került, például bekerült a pakliba a kórház világa külön témaként (9. téma), amely az egészségügyi ellátással kapcsolatos jogi információkat jeleníti meg.

A nem beszélő gyermekekkel való munka során szembesültek a pedagógusok azzal, hogy a bántalmazás témaköréhez kapcsolódó személyes vészjelzés kialakításával egy külön kártyának kellene foglalkoznia, hiszen a nonverbális módon kommunikáló gyerekeknek különösen fontos azt megtanulniuk, hogy egy bántalmazó helyzetben hogyan reagáljanak adekvátan. Csaphatnak zajt, kiáltással, esetleg tárgyak leverésével is jelezhetik, ha valaki bántotta őket. Ennek a tudásnak a birtokában válhatnak az őket érintő cselekmények passzív elszenvedőiből életük aktív irányítóivá. További érdekesség, hogy az eredeti pakliban az intézetekkel kapcsolatban két külön téma is szerepelt: mit tehetek, ha intézetbe akarnak küldeni, és hogyan védhetem meg ott magamat? Ez a két téma egy témává sürüsödött össze (4. téma), és maradtak azokat a helyzeteket bemutató kártyalapok, amelyek fontos útmutatóként szolgálnak ahhoz, hogy hogyan lehet megvédeni magunkat egy bentlakásos szociális intézetben.

A MONDO tehát azokat az akadályokat veszi sorra, amelyekkel ma Magyarországon egy fogyatékossággal élő ember találkozhat az élete során. Egyediségét az adja, hogy az elvont emberi jogi témák magas absztrakciós szintjét lefordítja a gyermekek számára is érhető nyelvezetre. A kártyák képi világa barátságos, ennek köszönhetően a nehezebb témák feldolgozására is lehetőség nyílik (pl. bántalmazás, szociális intézetek). A kártyák konkrét helyzeteket mutatnak be, és konkrét útmutatást adnak abban, hogy mit kell csinálni adott veszélyhelyzetek elkerüléséhez, illetve hogyan lehet megvédeni magunkat egy adott helyzetben, kitől lehet segítséget kérni.

A kártyaformátum továbbá lehetőséget ad arra, hogy a gyermek/felnőtt elé csak a számára releváns szituációt ábrázoló kártya, téma kerüljön, figyelembe véve életkorát, képességeit, érdeklődését, esetleg egy éppen aktuális életeseményt. A megértést támogatandó a pakliban megtalálhatók karakterkártyák, amelyek segítségével könnyebben el tudunk igazodni a rendszer különböző szereplői között (pl. bíró, ügyvéd, gyámhatósági ügyintéző, ellátottjogi képviselő).

\section{MONDO-témák az iskolában}

A témák között szerepelnek az iskolák mindennapjait érintő kérdések, ilyenek például a gondozás, barátság, párkapcsolat, de az iskolai élettel összefüggésbe hozható akár az egészségügyi ellátás (iskolaorvosi vizsgálatok) vagy a bántalmazás (bullying) témaköre is. Vannak témák, amelyek egyéni élethelyzetek felmerülése esetén, illetve a nagykorúság elérésével válnak húsbavágóvá, ilyenek például a gondnokság, a bentlakásos szociális intézetek, az önálló életvitel, az ügyintézés és a szavazás. Az iskola feladata az önálló, felnőtt életre való felkészítés, emiatt fontos, hogy a gyerekek elsajátítsák az iskolai éveken túlmutató témák ismeretanyagait is.

A MONDO-témák felosztásában egyrészt tükröződnek az emberi jogi diskurzusban tematizált problémakörök, másrészt a pedagógiai és gyógypedagógiai szempontú fejlesztési területek is közvetetten megjelennek az emberi jogi témákkal átfedésben. Az emberi jogi diskurzus felől például a cselekvőképesség korlátozhatósága kapcsán a gondnokság, az intézménytelenítési törekvések kapcsán a bent- 
lakásos szociális intézmények és a közösségi, önálló életvitel témakörei említendők meg. A gondozás, a barátság és a párkapcsolat témakörein belül megjelenő helyzetek a magánszférával, a magánélethez való joggal hozhatók összefüggésbe. A választójoggal kapcsolatos információk külön témakört érdemeltek, ez a nemzetközi emberi jogi megközelítés markáns álláspontjára vezethető vissza, miszerint a fogyatékossággal élő emberek aktív, illetve passzív választójoga soha nem korlátozható csak azért, mert valaki valamilyen vélt vagy valós fogyatékossággal él.

A MONDO témakörei:

1. Tisztelettel segítsenek, gondozzanak.

2. Ne bántsanak!

3. Miért ne helyezzenek gondnokság alá?

4. Az intézetben is megvédhetem magam.

5. Élhetek a közösségben.

6. Ismerkedhetek, barátkozhatok.

7. Lehet párom és saját családom.

8. Intézhetem az ügyeimet.

9. Dönthetek a kórházban.

10. Szavazhatok.

A témákban tükröződnek az emberi jogi diskurzusban tematizált rendszerszintü problémák, azonban félrevezető lenne azt gondolni, hogy a MONDO kizárólag a jogi perspektívából érdekes, a jog számára megfogható témákat dolgozza fel. A pedagógiai, gyógypedagógiai gyakorlat számára mindennapi kihívásokra reflektálnak a gondozás, barátság és a párkapcsolat témakörein belül megjelenő helyzetek, de alaposabb belegondolva rájövünk arra, hogy valójában az összes MONDO-téma kapcsolható iskolai tantárgyakhoz. A MONDO-témák kapcsolódási pontjai az iskolai tantárgyak fejlesztési követelményeivel a MONDO pedagógai segédanyag mellékletében megtalálhatóak. A melléklet az enyhe értelmi fogyatékossággal élő tanulók kerettantervi kapcsolatait veszi sorra az 5-8. évfolyamok vonatkozásában (Juhász-Vass \& Kapronczay, 2016)

Első pillanatra azt gondolhatnánk a témakörökröl, hogy hiszen ezek evidens módon elökerülnek az iskolában, amikor az szükséges. Ezzel szemben a Csillagház pedagógusai azzal szembesültek, hogy a MONDO-beszélgetéseknek köszönhetően olyan értékes információkat tudtak meg a gyermekektöl, amelyek korábban nem kerültek a felszínre. Ilyen volt például, amikor a MONDO használatát követöen egy kislány képes volt megfogalmazni azt, hogy zavarban volt az iskolai orvosi vizsgálat során, amikor le kellett vetkőznie idegen felnőtt férfi társaságában (a segédeszközt gyártó cég egyik férfi képviselője volt jelen). Az első témakörben (Tisztelettel segítsenek, gondozzanak.) szerepel egy kártya, amely hasonló helyzetet ábrázol. A kártyával kapcsolatos beszélgetésnek köszönhetően a gyermek saját érzéseivel kapcsolatos, hiányos szókészlete bővült (meg tudta fogalmazni, hogy abban a helyzetben zavarban van), és a beszélgetés során megtapasztalhatta, hogy kifejezheti a véleményét egy rossz érzésével kapcsolatban.

Az a felismerés, hogy egy bevett helyzetnek nem kell feltétlenül úgy lennie, ahogy azt megszoktuk, mind a gyermek saját önérvényesítése szempontjából, mind az iskola gyermekközpontú, önkritikus müködésének szempontjából fontos tapasztalat. Érdekességként megemlítendő, hogy máskor a MONDO használata a spe- 
ciális iskolai védőburokra, a mozgáskorlátozott diákok világról alkotott meglepően hiányos képére világított rá: egy mozgáskorlátozott kisfiú arra a kérdésre, hogy mit csinálna akkor, ha valaki megütné, azt válaszolta, hogy „megölelem.” Ezeknek és hasonló tanulói visszajelzéseknek köszönhetően az iskolák képesek finomhangolni, gyermekbarátabbá tenni a gyakorlatukat, vagy szembesülve az iskolai óvó-védő környezet esetleges hátulütőivel, célzottan foglalkozni bizonyos fontos témákkal.

\section{A KÉPZÉSEK FELÉPÍTÉSE}

A pedagógusok sokszor azzal az elvárással jönnek a workshopra, hogy megtanulják, hogyan lehet a MONDO-val játszani. A MONDO-nak jelenleg azonban nincs egy konkrét játékszabálya. A kártyaformátumnak köszönhetően sokféleképpen lehet a kártyákkal dolgozni, a különböző feldolgozási lehetőségeknek csak a pedagógus kreativitása, fantáziája szab határt. Ebből az következik, hogy a képzés kettős célt szolgál: egyrészt magukat a pedagógusokat jogtudatosítani, vagyis a MONDO-témákat illetően információkat átadni, másrészt módszertani támogatást nyújtani abban, hogy miként használhatják a MONDO-t iskolai keretek között.

A képzésen nincs idő arra, hogy minden témában elmerüljünk, mindössze egykét téma jogi hátterére tudunk részletesebben kitérni (pl. gondnokság), beszélni az ellátórendszer útvesztőiről (pl. szociális intézetek). Fontos beszélgetni a gondnokság és a támogatott döntéshozatal közti jogi és szemléletbeli különbségekről, tisztázni az emberi jogok és a gyógypedagógia közti értékazonosságot. A gondnokság kapcsán ez világos: a helyettes döntéshozatal jogintézménye mindazon gyógypedagógiai alapvetések ellen hat (önálló döntés támogatása, önálló életvitelhez szükséges készségek, képességek fejlesztése szükségletorientáltság, normalizáció és a participáció elve), amelyek alapján a gyógypedagógus éveken keresztül dolgozik a gyermekkel. Sokszor a pedagógusok a képzésen gondolnak bele először a gondnoksági rendszer hátulütőibe, hogy az önrendelkezés semmibevétele társadalmilag hátrányos következményekkel jár, hiszen a fogyatékossággal élő emberek döntési lehetőségeinek megvonása személyiségrombló hatású. Beszélünk még a bentlakásos szociális intézményi elhelyezés és a gondnokság közötti szoros összefüggésröl, vagyis a gondnokság azon társadalmi funkciójáról, hogy gyakran a fogyatékossággal élő emberek döntési jogának korlátozása az intézeti elzárás eszköze, amit az is alátámaszt, hogy az intézetben élö fogyatékossággal élő emberek többsége gondnokság alatt áll.

A témák tartalmi feldolgozása mellett a workshop arra fókuszál, hogy a kártyák hogyan segíthetik a pedagógusokat a munkájuk során. Példákat gyűjtünk arra, hogy adott téma melyik órára vihető be. Mivel a tíz témakör nem szigorúan pedagógiai logikát követve, tantárgyak mentén került kialakításra (sarkalatos emberi jogi területek tükröződnek bennük), ezért ez a feladat abban segít a tanároknak, hogy a témákat konkrét tantárgyakhoz kapcsolják. Például osztályfönöki órán egy, az egész osztályt érintő konfliktus kapcsán lehet a MONDO-kártyák segítségével beszélgetni a diákokkal arról, hogyan bánunk egymással, mi az, amit nem teszünk meg a másikkal. Irodalomórán fel lehet például dolgozni a barátság, a szerelem témaköreit egy olvasmány kapcsán. Állampolgári ismeretek vagy etika órán eshet szó az önálló döntés fontosságáról (gondnokság), a szavazással kapcsolatos, vagy a 
sikeres ügyintézéshez szükséges információkról. Ezt követően arról gondolkodunk, hogy módszertanilag hogyan dolgozhatók fel a MONDO-témák az adott iskolában, miként használhatók a kártyák a pedagógiai munka során. A tanárok 2-4 fös csoportokban egy-egy témát kapnak, kiválasztják a számukra legfontosabb kártyát, majd közösen gondolkodnak arról, hogy a kártyák segítségével miként lehet az adott témát a tanulókkal játékosan feldolgozni.

\section{A KÉPZÉSEK TAPASZTALATAI}

A workshopok fele után anonim visszajelzéseket kértünk a résztvevőktől e-mailben. A 17 válaszadó több mint fele nagyon hasznosnak ítélte a képzést. 1-5 Likert-skálán 4-en jelezték, hogy hasznos, 4-en pedig közepesen hasznosnak ítélték a workshopot.
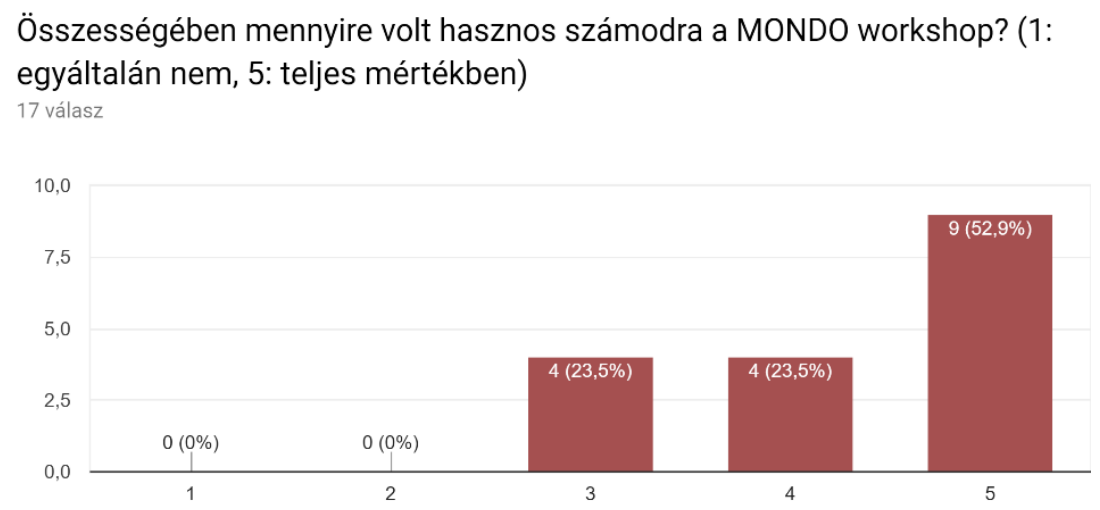

\section{3. ÁBRA: A MONDO WORKSHOPOK HASZNOSSÁGI MUTATÓJA}

Arra a kérdésre, hogy milyen keretek között és kivel dolgozott a szakember a MONDO-val többek között ezeket a válaszokat kaptuk: tanítás utáni mentorcsoport lányoknak foglalkozás keretében; állampolgári ismeretek tanóra keretén belül halmozottan sérült 15-20 éves fiatalokkal; fejlesztő foglalkozáson autista tanulóval; önérvényesítő foglalkozáson a suliban.

Arra a kérdésre, hogy milyen módon dolgozott fel egy adott témát a pedagógus például, ezek a válaszok érkeztek: minden gyerek kártyát húzott, majd sorrendben megbeszéltük a tartalmukat, melyekhez PPT-t készítettem; párban beszélgetés a kártyákról; memóriajáték; társasjátékot a helyes és helytelen viselkedési formák megbeszéléséhez; kiválaszthatta az őt érdeklő témát, és arról beszélgettünk egyéni fejlesztés keretében; kártyákkal kapcsolatos igaz-hamis állítások megbeszélése.

Összességében a képzések tapasztalatai sokfélék, egy-egy tantestületen belül is nagyon eltérőek a pedagógusok reakciói. Van, aki csillogó szemmel hallgatja végig a workshopot, aktívan hozzászól, drámapedagógiai ötletekkel áll elő arról, miként fogja a MONDO-kártyákat használni a munkája során. Van viszont, aki a kezébe se hajlandó venni a kártyapaklit: „ő ezzel nem ért egyet.” A gyermekvállalással kapcsolatos kérdések gyakran vita tárgyát képzik, volt, aki erről így nyilatkozott: 
„Ezeknek (értelmi fogyatékossággal élő felnőtt személyeknek) lehessen gyereke? $\mathrm{Na}$, az kizárt."

A fogyatékossággal élő tanulói csoportok heterogenitása miatt nagyon vegyes képet mutat, hogy a tanárok hogyan reagálnak a MONDO-ra, hiszen a tanulók fogyatékossága határozza meg, hogy a MONDO-kártyák hogyan használhatók az iskolai emberi jogi oktatásban. A különböző képességű tanulókkal foglalkozó pedagógusok reakcióinak rövid bemutatása következik. Szinte az összes, tanulásban akadályozott (enyhe értelmi fogyatékossággal élő), jellemzően roma tanulókat oktató-nevelő pedagógusokból álló csoport számára tartott képzés visszatérő momentuma, hogy a gyermekjogokról való beszélgetés elején kifakadnak a tanárok: csak jogokról lesz itt szó? És mi a helyzet a kötelességekkel? Gyakran elhangzott vélekedés a tanárok részéröl, hogy a gyerekek nagyon is tisztában vannak a jogaikkal, ismerik és érvényesítik azokat nagyon is jól.

Sőt, a hozzászólások alapján a tanárok megélése gyakran az, hogy a gyerekeknek túl sok joguk van. Sok pedagógusban pusztán a gyerekjogok felemlegetése zsigeri ellenállást vált ki. A jogok tartalmának kifejtése előtt sokszor a jogkorlátozás módja az, amire a pedagógusok rögtön kíváncsiak. Meddig terjed egy kirívó magatartású gyerek joga az iskolába járáshoz? Meddig kell a többi gyereknek, a pedagógusnak elviselnie egy kezelhetetlen magatartást?

Minél problémásabb a gyerek, annál inkább jogosnak tủnik a jogainak a korlátozása, annál inkább kezdünk el kötelességekröl beszélni. Egy nagyon gyakori téves elképzelés, hogy a jogok és a kötelezettségek egyensúlyban legyenek egymással. Minden képzésen fontosnak tartom tisztázni azt, hogy az emberi jogok senkitől sem vonhatók meg, hiszen azok emberi mivoltunknál fogva megilletnek minket.

Általában egy mérleg-hasonlattal szoktam szemléltetni a jogok és kötelezettségek közötti összefüggést. Az emberi jogi megközelítés szerint a mérleg egyik serpenyőjében az állampolgár alapjogai vannak, míg a másik serpenyőt nem az egyén kötelességei húzzák, hanem az állam kötelezettsége, hogy tevőleges cselekedettel (pl. kormányzati közszereplő értelmi fogyatékossággal élő embereket sértő megnyilvánulása), vagy mulasztással (pl. közszolgáltatásokhoz való egyenlő esélyű hozzáférés biztosításának hiánya) ne sértse meg az állampolgárok emberi jogait. Tehát a jogok és kötelességek az egyén és az állam viszonyában (vagy magánjogi viszonylatban, interperszonális szinten, több jogalany kapcsán) érhetők tetten. Ezért a jogok kötelezettségekkel való balanszírozása egy egyén tekintetében emberi jogi szempontból nem értelmezhető.

A pedagógiai nevelö-oktató szemlélet azonban a személyiségfejlesztés felöl közelítve a jogok és kötelezettségek közötti összefüggéseket könnyen vonatkoztatja egy adott tanulóra. A pedagógusok a jogtudatosítást először gyakran úgy értelmezik, hogy a feladat a jogok és kötelezettségek közötti egyensúlyi állapot kialakítása egy tanulóval kapcsolatban. A gyermek szocializációja, érzelmi, értelmi, képességeinek fejlesztése érdekében a pedagógusok a jogok és kötelezettségek egyensúlyát jellemzően egy tanulóra vonatkoztatva értelmezik, és gyakran elfelejtik az állam szerepét az emberi jogi jogsérelmek kialakulásában, elkövetésében.

Fontos tehát kiemelni, hogy a jogok gyakorlása nem tehető függővé a kötelezettségek teljesítésétől. Például, ha egy gyerek rosszul viselkedik, nem veszíti el azon jogát, hogy ne vessék alá kínzásnak, embertelen vagy megalázó bánásmódnak, büntetésnek. Tehát adott esetben nem lesz kevesebb joga valakinek amiatt, mert 
nem teljesítette valamely kötelezettségét. A kötelezettségek elmulasztása (pl. a tanuló elkésik, nem írja meg a leckéjét, nem figyel az órán, nincs nála a felszerelése) nem vezet automatikusan a jogok korlátozhatóságához. Adott esetben a fegyelmezetlen, nem kötelességtudó tanulóval szemben a kötelezettségek megszegését lehet szankcionálni a mulasztással arányosan, és azzal összefüggésben (pl. fekete pontot kap, mert nem hozta magával a füzetét). Jogsérelem elkövetése esetén (alapvető szabályok felrúgása, mások jogainak megsértése) pedig azokat a büntetéseket lehet jogszerüen alkalmazni, amelyeket az adott oktatási intézmény törvényi kereteket figyelembe véve megalkotott házirendje előír, illetve lehetővé tesz.

Az egyéni szabadság és a közösségi célok közötti ellentmondások feloldására tett kísérlet tehát csak akkor lehet sikeres, ha a tanár az individuális szempontokat nem tartja feláldozhatónak a közösség érdekében. A tanár nem alázhatja meg a többi gyermek előtt a renitens tanulót, nem keverhet le neki pedagógiai célzattal egy pofont. A tanulót sosem lehet eszközként felhasználni valamilyen nevelési cél eléréséhez, példa statuálása gyanánt, az emberhez méltó bánásmód követelményeit minden esetben be kell tartani. Emiatt a házirend nyilván nem helyezhet kilátásba testi fenyítést vagy megalázó büntetést (testi és lelki erőszak különböző formáit), hiszen az sértené a tanuló személyiségét, emberi méltóságát.

Gyakran tapasztaltam azt, hogy félelmet kelt a tanulásban akadályozott tanulókat nevelő tanárokban az a gondolat, hogy a gyerekekkel a jogaikról beszélgessenek. Mintha ezzel kinyitnák Pandora szelencéjét, és a gyerekek jogtudatossága iskolai anarchia kirobbanásához vezetne. Egy gyógypedagógus ezt így fogalmazta meg: „Ezek a gyerekek már így is ellesték a szüleiktől azokat a kifejezéseket, hogy »feljelentelek« vagy "távoltartást kérek«, amelyeket előszeretettel vágnak a fejemhez."

A jogoktól való ódzkódás az iskola demokratikus müködésének hiányát jelzi. Egy emberi jogokkal ellenséges iskolai légkörben a tanárok keze meg van kötve, a gyermekek és a pedagógusok jogai ilyenkor könnyen sérülhetnek. Fontos azt megerősíteni a tanárokban, hogy a jogtudatosító tevékenység kölcsönösségre, egymást tiszteletére tanít. A jogtudatosítás a személyiségfejlesztés részének tekinthető, a jogtudatos magatartás kialakítására szolgál, mások jogainak tiszteletben tartására tanít. A jogtudatosításból nem következik, hogy a gyerekek jogaik tudatában azokkal vissza fognak élni. Viszont egy biztos: a jogokkal való ismerkedés során a gyerekek önismeretet tanulnak, társas kompetenciájuk fejlődik, a világról alkotott képük gazdagodik.

A gyerekjogokkal szembeni ellenállást csökkenti annak a gondolatnak a tudatosítása, hogy a jogok nem vákuumban léteznek. Fontos megértetni a gyerekekkel azt, hogy társaik is ugyanolyan emberi jogokkal rendelkeznek, mint ők maguk. Egy renitens gyermek esetében annak a ténynek a tudatosítása, hogy másoknak is ugyanazok a jogai, mint neki, és azokat tiszteletben kell tartani, célravezetőbb lehet, mint a kötelességek sulykolása. A tanár feladata pedig az, hogy megfelelö eszközöket adjon a diák kezébe, mellyel úgy tudja megvédeni a jogait, hogy közben másokét ne sértse.

A jogelméleti dilemmák feloldását követően a tanárok sok példát hoznak fel, hogy hogyan használnák a gyermek életkorát és képességeit figyelembe véve a tanulásban akadályozott tanulókkal a kártyákat. Például beszélgetés az ábrázolt helyzetek lehetséges jelentéséröl, saját tapasztalatok megosztása, szerepjáték, bábozás, szociális történetek készítése. A tanulásban akadályozott tanulók esetében 
az absztrakció magas fokát feltételező, értő, készségszintű olvasás is szóba jön, ezért a képek mellett van, aki a kártyák üzeneteit is el tudja olvasni. Több tanártól érkezett visszajelzés, hogy a kártyák autizmus specifikus eszközként is megállják a helyüket, a letisztult és kontrasztos grafikának köszönhetően az érzelmek dekódolhatók azon gyermekek számára is, akiknek nehezen megy mások érzelmeinek, szándékainak értelmezése.

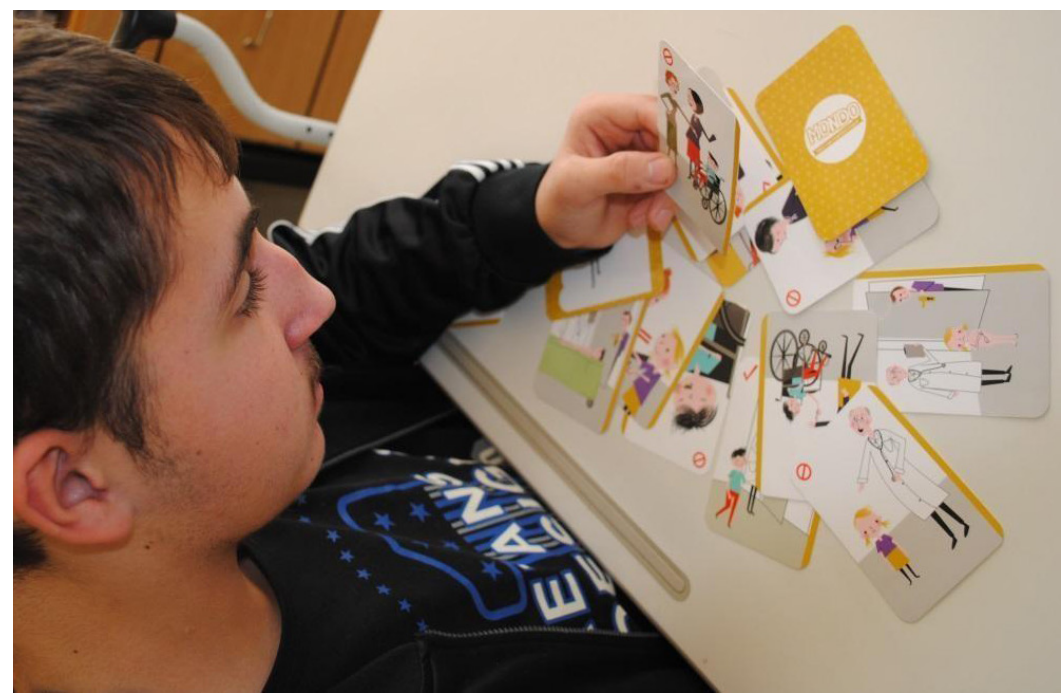

4. ÁBRA: ISMERKEDÉS A MONDO-VAL

A Christoph Hublow nevéhez füződő olvasásértelmezés szerint a tágabb értelemben vett olvasás kiterjed a szituációk, a képek, képsorok, vizuális jelek megértésére is (Pál-Horváth, 2017). A képekkel való kommunikáció azon tanulók esetében kiemelt jelentőségű, akik az írás-olvasásig nem juttathatók el. Az olvasáshoz szükséges készségekben gyengén teljesítő, középsúlyos értelmi fogyatékossággal élő, illetve a nem, vagy alig beszélő tanulók számára a kártyákon szereplő képek az információhordozók. Ők ezeket a kétdimenziós képeket, szimbólumokat „olvassák le." Az ábrázolt helyzetet egészében vagy részleteiben felismerik, kapcsolatba hozzák saját élményeikkel. Ezáltal a statikus képek jelentéstartalma rávetül a valóság „képeire”, a tanuló összekapcsolja az emlékeivel, így a képek előhívják a valóság egy darabjának képzetét.

Külön kiemelendők a súlyos és halmozott fogyatékossággal élő tanulókat oktató pedagógusok visszajelzései. A fejlesztő nevelés-oktatás irányelvének személyközpontú szemlélete alapján megvalósuló gyógypedagógiai gyakorlat és az emberi jogi mozgalom közötti értékazonosság szembetűnő módon tetten érhető [3. melléklet a 32/2012. (X. 8.) EMMI rendelethez]. Az alapelvek mentén történő fejlesztés kiemelt célja az önrendelkező életre való felkészítés a sérülés fokától függetlenül. Ez a szemlélet a személyes autonómiát és döntési szabadság jelentőségét hangsúlyozó emberi jogi gondolkodáshoz szervesen illeszkedik. Gyakorlati szempontból a „fejlesztős” tanárok azonban nehezen tudják elképzelni, hogy hogyan használják a kártyákat a fejlesztő osztályokban. 
A kártyákkal akkor lehet dolgozni, ha a képek érthető információval szolgálnak a tanuló számára, és a megjelenített szituációkat összefüggésbe tudja hozni a saját tapasztalataival. A MONDO képi síkon rögzített vizuális információk értelmezéséhez szükséges elvonatkoztatás magasabb fokát feltételezi: a képek olvasását. Azonban vannak olyan magas támogatási szükségletű, súlyos és halmozott fogyatékossággal élő tanulók, akik számára a jelentéshordozókat a cselekvő személyek jelentik, valamint mozgó és áló tárgyak ismerős helyzetekben. Ez azt jelenti, hogy a súlyos és halmozott fogyatékossággal élő tanulók szituációkat olvasnak, ezért esetükben a MONDO-t adaptálni szükséges, a kártyák kétdimenziós ábrái számukra nem értelmezhetők.

A kártyákon megjelenő helyzeteket észlelésen és érzékelésen alapuló kommunikációs, úgynevezett „bazális” helyzetekbe szükséges illeszteni, az egyéni képességekhez igazodó, nonverbális augmentatív és alternatív (AAK) kommunikációs eszközök használatával kiegészítve. Az AAK jelenthet beszéd helyett mimikát, a hétköznapi életből vett gesztusokat, jeleket vagy tárgyakat, fotókat, szimbólumokokat, piktogramokat, szignálszavakat, vagy akár szóképeket is. A kommunikációba és cselekvésbe ágyazott tanulás során a tanulók saját élményeiken keresztül ismerhetik fel a szituációk jelentését, emlékeiket előhívva tudják hosszú távon tudatosítani a kártyák üzeneteit. Az összefüggések felfedezésével a tanulók egyre jobban megismerik önmagukat, megtanulnak adott szituációkhoz kapcsolódó viselkedésformákat. Ezáltal képesekké válnak érzéseik kifejezésére, megtanulnak más emberekkel kontaktusba kerülni, egyre jobban eligazodnak a külvilágban.

\section{JAVASLAT A GONDNOKSÁG TÉMA FELDOLGOZÁSÁHOZ}

A Debrecen-Nagytemplomi Református Egyházközség Immánuel Otthona, Általános Iskola és Fejlesztő Nevelés-Oktatást Végző Iskolája által kifejlesztett „Enyém a döntés!" c. tananyagok 30 darab 45 perces óratervet tartalmaznak, amelyek konkrét ötletekkel, feladatokkal, segédanyagokkal segítik a MONDO-témák pedagógiai feldolgozását. A tananyagok tanulásban és értelmileg akadályozott gyermekek számára is elkészült, elérhetők a TASZ honlapján (http://mondo.tasz.hu/segedanyagok). Önismereti játékok, társas kompetenciát fejlesztő feladatok vezetik fel az önálló döntéshez szükséges ismereteket, készségeket fejlesztő foglalkozásokat, majd jutnak el a tanulók az egyes MONDO-témák, illetve a könnyen érthető Gyermekjogi ENSZ Egyezményben és az Emberi Jogok Egyetemes Nyilatkozatában szereplő alapelvek és jogok tartalmának játékos feldolgozásáig. 
1. TÁBLÁZAT. TANULÁSBAN AKADÁlYOZOTT TANULÓK SZÁmÁRA tANANYAG A MONDO TÉMÁK FELVEZETÉSÉHEZ, FELDOLGOZÁSÁHOZ (FODOR-GuLYÁs, 2015, PP. 27)

\begin{tabular}{|c|c|c|}
\hline Modul felépítése & Órák/Témák & [? Idalszám \\
\hline \multirow{6}{*}{$\begin{array}{l}\text { I. Önismeret } \\
\text { (6 óra) }\end{array}$} & 1. óra "Ez én vagyok" & 3 \\
\hline & 2. óra "Te és én" & 4 \\
\hline & 3. óra „Milyen a kapcsolatom másokkal?” & 5 \\
\hline & 4. óra "Kiben bízhatok?" & 6 \\
\hline & 5. óra Gyakorló óra - „Játsszunk!” & 7 \\
\hline & $\begin{array}{l}\text { 6. óra Modulzáró alkotó óra - „Az én házam, az én } \\
\text { váram” }\end{array}$ & 9 \\
\hline \multirow{16}{*}{$\begin{array}{c}\text { II. Támogatott } \\
\text { döntéshozatal- } \\
\text { Út a támogatott } \\
\text { döntéshozatalig } \\
\text { (20 óra) }\end{array}$} & 7-8. óra-A döntés & 10 \\
\hline & 9-10. óra - A döntés lépései & 13 \\
\hline & 11-12-13. óra-Minden napi döntéseink & 15 \\
\hline & 14. óra-Életünk nagy döntései & 18 \\
\hline & 15. óra-Most én döntök & 19 \\
\hline & 16. óra - Szükség és vágy & 20 \\
\hline & 17. óra-Gyakoroljunk! & 21 \\
\hline & $\begin{array}{l}\text { 18. óra-Önvédelem: Tisztelettel segítsenek, } \\
\text { gondozzanak! }\end{array}$ & 22 \\
\hline & 19. óra - Ne bántsanak! & 23 \\
\hline & 20. óra - Ne helyezzenek gondnokság alá! & 24 \\
\hline & 21. óra-Ne zárjanak intézetbe! & 25 \\
\hline & 22. óra - Az intézetben is megvédhetem magam! & 26 \\
\hline & 23. óra-Ismerkedhetek, barátkozhatok! & 27 \\
\hline & 24. óra - Lehet párom és saját családom! & 28 \\
\hline & $\begin{array}{l}\text { 25. óra - Gyakorló óra } \\
18 \text { évet betöltött fiataloknak: Intézhetem az } \\
\text { ügyeimet! }\end{array}$ & 29 és 31 \\
\hline & $\begin{array}{l}\text { 26. óra - Gyakorló óra } \\
18 \text { évet betöltött fiataloknak: Élhetek közösségben, } \\
\text { élhetek a politikai jogaimmal, szavazhatok! }\end{array}$ & 30 és 32 \\
\hline $\begin{array}{l}\text { III. Jogom van hozzá! } \\
\text { (4 óra) }\end{array}$ & $\begin{array}{l}\text { 27-30. óra - Egyezmény a gyermek jogairól } \\
18 \text { évet betöltött fiataloknak: Emberi Jogok Egyetemes } \\
\text { Nyilatkozata }\end{array}$ & 33 \\
\hline
\end{tabular}

A tanuló életkorától, képességeitől függően a „gondnokság” témát érdemes a döntés fogalma köré felépíteni, akár mesék feldolgozásának segítségével lehet a gyerekekkel arról beszélgetni, hogy mit is jelent a döntés. Ehhez kapcsolódóan a gyerekek mindennapi életét érintően gyűjthetünk példát arra, hogy milyen döntéseket hoznak nap mint nap, milyen kérdésekben nem dönthetnek még. Mit jelent a jó és a rossz döntés, hogyan tájékozódunk, mielőtt meghozunk egy fontos döntést? Mi a különbség a szükség és a vágy között? Több órát is tölthetünk a döntés fogalmának gyakorlati, életpraktikus szempontú megvitatásával, mire eljutunk az önálló döntés fontosságához, a választási szabadság jelentőségéhez.

Ezen a ponton példákat gyűjthetünk arra, hogy milyen döntéseket hozhat meg egy gyermek, egy fiatal felnőtt és egy idős ember. Beszélhetünk a döntések következményeiről, a cselekedeteinkért vállalt felelősségről. Beszélhetünk arról, hogy mi a különbség aközött, hogy valaki helyettem dönt, vagy hogy segít nekem jó döntést hozni. Itt kitérhetünk a gondnokság és a támogatott döntéshozatal jogintézményei közötti különbségekre, jogérvényesítési lehetőségek ismertetésére. A TASZ könynyen érthető tájékoztatója a támogatott döntéshozatalról elérhető az interneten, ami további segítséget nyújt a diákoknak a téma megértésében (Mllanovich \& Verdes, 2017). 


\section{ÖsszefoglaLÁs}

A workshopok végén többször kaptam olyan visszajelzést, hogy az emberi jogi szemlélet nagyon messze áll a mindennapi pedagógiai gondolkodástól, a heurisztikus problémamegoldástól. Nem egyedülálló ez a visszacsatolás, vagy az ehhez hasonló visszajelzés: „Ezek a jogok nagyon újszerüek számomra, én nem így gondolkodom." Sokan kiemelik, hogy a jogtudatos magatartás saját magukra sem jellemző, így hogy várják azt el a diákjaiktól?” „Mi nem úgy szocializálódtunk, hogy ismerjük és érvényesítsük a jogainkat." Többen azzal zárják a workshopot, hogy meglepő volt számukra azzal szembesülni, hogy mennyi emberi jogi relevanciája van a munkájuknak.

A képzések tapasztalatai azt mutatják, hogy a jogtudatosság gyakran nem szerepel a pedagógusok mindennapi fogalomkészletében. Az iskolában történő jogokkal való ismerkedés megvalósulásának hiányára a pedagógusok kötelesség-központú gondolkodása, bizonyos esetben a témával szembeni kifejezett ellenállása mutat rá. A pedagógusok kompetens jogi tudás hiányában (jogi alapvetések, egyes jogok pontos tartalma, a jogkorlátozás jogszerủ módjai) jogtudatosítás miatti anarchia kirobbanását vizionálják az iskolában. Az a vélekedés, hogy veszélyes, ha a gyerekek megismerik a jogaikat a tanárok ismerethiányára vezethető vissza.

Másképpen megfogalmazva: a tanárok nevelő-oktató munkájának keretrendszerét jellemzően nem az emberi jogok adják. Ritkán kötik össze a tantárgyakban megjelenő tevékenységeket, fejlesztési követelményeket a kapcsolódó emberi jogokkal. Pedig ahhoz, hogy jogtudatosító tevékenységet tudjanak végezni, nekik maguknak is tisztában kell lenniük a gyermekjogok pontos tartalmával, azok öszszefüggéseivel.

Azon túl, hogy a pedagógusok feladata, hogy ismeretátadáson, készségfejlesztésen, attitűdformáláson keresztül a diákok felé közvetítsék az emberi jogok védelmének fontosságát, az iskolai jogkorlátozás megengedhetőségét végső soron a pedagógus emberi jogokról alkotott felfogása határozza meg (a hatályos törvények alapján). Ahhoz, hogy ne történhessenek ún. „pedagógiailag indokolt” törvénysértések, az szükséges, hogy a pedagógusok az emberi jogokra ne béklyóként tekintsenek (amik eszköztelenné teszik őket a tanulók fegyelmezése során). Ehhez elengedhetetlen a tanárok további jogtudatosítása.

A kétórás workshop nem tud megfelelő alapot adni ahhoz, hogy az emberi jogok rendszere egyfajta nevelési útmutatóvá váljon a tanárok számára. A MONDO egyrészről felkészültséget, tájékozottságot igényel a pedagógus részéről, másfelől nagyfokú egyéni adaptációra ad lehetőséget. A szakembereknek a képzést követően még szükséges időt szánniuk a MONDO-témák mélyebb megismerésére, az összefüggéseket átlátására, hogy a felmerülö témákat az óráikba be tudják illeszteni, vagy azokat tematikusan fel tudják dolgozni.

A résztvevők azt is kiemelik, hogy a szülők számára is nagyon fontos lenne a MONDO ismerete.

A pedagógusok visszajelzései alapján a MONDO a fogyatékossággal élő gyermekek jogairól komplex képet nyújt és segíthet nekik a különböző órákra való felkészülésben (föleg osztályfönöki, etika, társadalmi ismeretek). Míg a szegregált intézményekben dolgozó gyógypedagógusok közvetlenül a fogyatékossággal élő tanulók és családjaik társadalmi tudatosságát tudják növelni a MONDO segítségével, az 
integrációban dolgozó, utazó gyógypedagógusok, illetve a többségi pedagógusok és más szociális szakemberek kezében a MONDO érzékenyítő foglalkozások témaválasztásában is segítséget nyújt, háttérinformációval szolgál.

A MONDO abban támogatja meg a szakembereket, családokat, hogy a fogyatékossággal élő személyek is hozzáférhessenek azokhoz az információkhoz, amelyek tudatában ki tudnak állni a saját jogaikért. A fogyatékossággal élő személyek jogtudatosításának sikeressége azon is múlik, hogy a pedagógus és a szülő hogyan használja a MONDO-t, amit saját ismeretei, szemléletmódja, módszertani repertoárja, kreativitása befolyásol, vagyis a fogyatékossággal élő személyek jogtudatosságának növekedése a pedagógus, a szülök teljesítményének függvényében értékelhető.

A jogtudatosság csökkenti a kiszolgáltatottságot. A gyógypedagógiai iskolák tanügyi dokumentumaiban hangsúlyosan jelenik meg, hogy a tanulók sajátítsák el a társadalmi beilleszkedéshez megkívánt szociális készségeket. De a szocializációhoz, a társadalomba való beilleszkedéshez szükséges alkalmazkodás mellett vajon eleget foglalkozunk-e a jogtudatossággal, az önérvényesítéssel? Az iskolai óvó-védő háló elvékonyodásával a felnőtt életbe kilépő fogyatékossággal élő fiatalok vajon fel vannak-e vértezve mindazokkal az ismeretekkel, készségekkel, attitüddel, hogy érvényesülni tudjanak ma Magyarországon?

\section{Irodalom}

Fodor-Gulyás E. (2015). „Enyém a döntés!” Tanulásban akadályozott tanulóknak szóló tananyaghoz kapcsolódó segédanyag pedagógusok számára, FSZK, FOF2015/175. Budapest: FSZK.

Juhász-Vass T., \& Kapronczay S. (2016). MONDO Kerettantervi kapcsolatok melléklet. http://mondo.tasz.hu/wp-content/uploads/MONDO-pedagogiai-segedanyag.pdf

Milanovich D., \& Verdes T. (2017). Én akarok dönteni az életemröl. Budapest: TASZ.

Pál-Horváth R. (2008). Olvasni? Egy más felfogásban (Középsúlyos értelmi fogyatékos tanulók olvasástanítása). https://docplayer.hu/12446381-Olvasni-egy-mas-felfogasban-kozepsulyos-ertelmi-fogyatekos-tanulok-olvasastanitasa.html

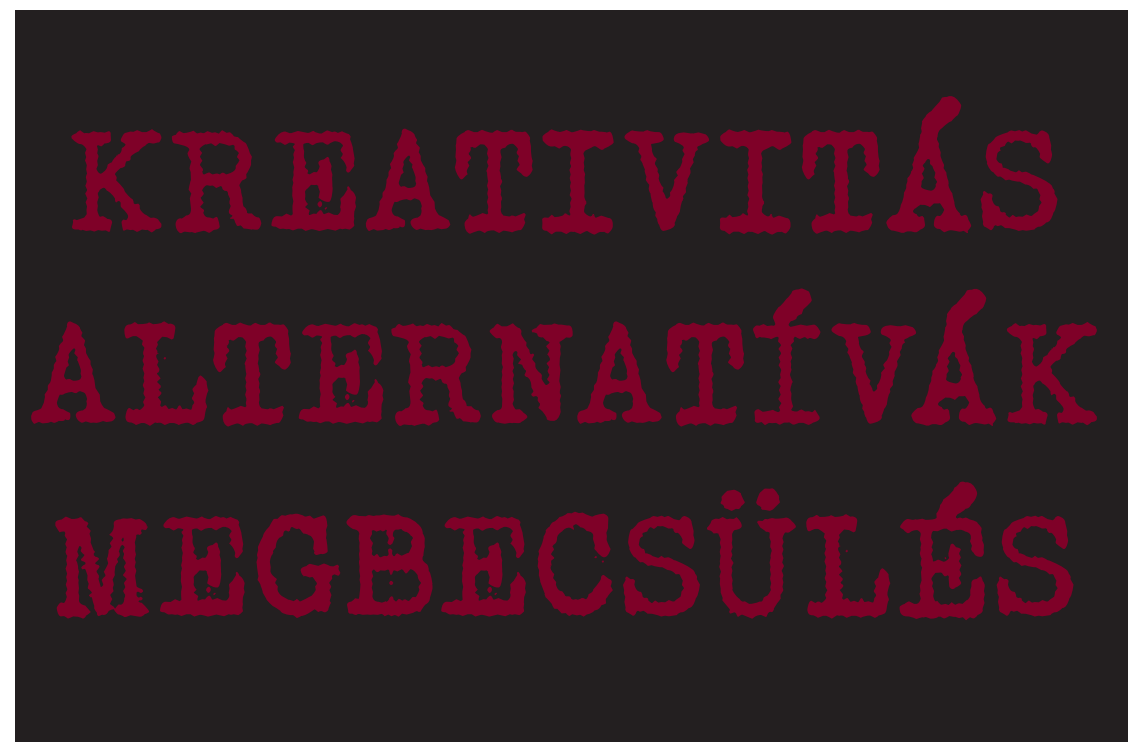

